\title{
Dietary carotenoids in normal and pathological tissues of corpus uteri
}

\author{
Ewa Czeczuga-Semeniuk, Sławomir Wołczyński
}

Department of Reproduction and Gynecological Endocrinology, Medical University of Białystok, Białystok, Poland

\begin{abstract}
Carotenoids and retinyl esters are the source of vitamin A in the human body and its natural derivatives takes part in the regulation of cell replication and differentiation in the human endometrium, may induce the leiomyoma growth and has a role in differentiation of endometrial adenocarcinoma. The aim of the study was to demonstrate the presence of carotenoids in tissues from the normal uterus and from various tumors of the uterine corpus, as well as to compare the total content, major carotenoids and $\%$ of carotenoids belonging to the provitamin A group between the tissues examined. Using three independent methods of chromatography (CC, TLC, HPLC) we analysed 140 human samples. We identified 13 carotenoids belonging to the eg. provitamin A group and epoxy carotenoids. In all the samples $\beta$-carotene, $\beta$-cryptoxanthin, lutein, neoxanthin, violaxanthin and mutatoxanthin were isolated. In normal tissues, the mean carotenoid content was the highest in the follicular phase endometrium $(9.9 \mu \mathrm{g} / \mathrm{g})$, while the highest percentage of carotenoids belonging to provitamin A group was found in the luteal phase $(18.2 \%)$. In the pathological group, the highest mean values were demonstrated for epithelial lesions $(8.0 \mu \mathrm{g} / \mathrm{g})$, and within this group - in endometrioid adenocarcinoma $(10.8 \mu \mathrm{g} / \mathrm{g})$. In both groups, violaxanthin, $\beta$-cryptoxanthin, lutein epoxide and mutatoxanthin were the predominant carotenoids. We have demonstrated that all uterine tissues show a concentration of $\beta$ carotene and $\beta$-cryptoxanthin, being the source of vitamin A. The highest total values of carotenoids obtained in the group of endometrioid adenocarcinoma seem to confirm certain enzymatic defects in carotenoid metabolism in the course of the neoplastic process or some metabolic modifications. The finding of astaxanthin - the major antioxidant among carotenoids - in $63 \%$ of tissues examined is also significant.
\end{abstract}

Key words: Carotenoids identification - Corpus uteri tissues - Neoplasms

\section{Introduction}

The function of carotenoids in humans is not clear, although we know that retinol (vitamin $\mathrm{A})$ is involved in vision-related processes, maintenance of differentiated epithelia, mucus secretion and reproduction. Animal studies have revealed that vitamin A and its derivatives (retinoids) play a primary role in the physiological development and growth of the uterine [1], while its natural derivative - retinoic acid can restore normal uterine epithelial cell differentiation in deficient animals [2]. $\beta$-carotene supply has a beneficial effect on the growth of the embryo and placenta [3,4]. A study of Schweigert et al. on gilts demonstrated that vitamin A content and distribution in uterine tissue was dependent on the stage of gestation [5]. Chew et al. showed that in cats fed diets containing $\beta$-carotene this carotenoid was subsequently

Correspondence: E. Czeczuga-Semeniuk, Dept. of Reproduction and Gynecological Endocrinology, Medical University of Białystok, 15-276 Białystok, M. Skłodowskiej-Curie 24A, Poland; tel.: (+4885) 7468343, fax.: (+4885) 7468818, e-mail: czeczuga@wp.pl taken up by corpora lutea and uterine endometrium, and also significantly increased the total content of uterine protein [6]. Also the uterine environment in pigs, apart estrogens, prostaglandin and several proteins, includes retinol [7]. Thus, carotenoid concentration in the mammalian uterine could regulate the uterine environment.

Vitamin A is provided to the human organism with food, in the form of retinyl esters (animal products) and carotenoids belonging to the group of provitamin A (vegetable products). Among them $\beta$-carotene is the most widely spread in nature. Its presence has been described in the majority of lower and higher plants [8]. In man, this carotenoid pigment absorbed with food is enzymatically converted into two vitamin A molecules. The multiple enzymes are capable of catalysing each of the steps required to convert dietary precursors to bioactive metabolites, such as retinal and retinoic acid. These steps can be catalysed by more than one enzyme and most of the enzymes involved are multifunctional [9]. So this process is complex. The retinoic acid, a natural metabolite of vitamin $\mathrm{A}$, takes part in the regulation of 
the cycles of cell replication and differentiation in the human endometrium [10], and decidualization of fibroblasts [11,12]. Tsibris et al. suggest that among inducers, apart from estradiol, the transcriptionally active PPAR $\gamma: R X R \alpha$ heterodimers and all-trans retinoic acid may regulate the leiomyoma growth and this mechanism is potentially reversible [13]. There has also been a suggestion that retinoic acid may take a role in differentiation of endometrial adenocarcinoma [14]. Deng et $a l$. assume that endogenous retinoic acid may play an important role in opposing the stimulatory effect of estrogen in the normal endometrium and potentially suppressing the development of endometrial hyperplasia and cancer [15]. It is likely that in rats retinoic acid produced endogenously by the uterus plays a major role in uterine cell biology, and this role is attenuated through the CRABPs [16]. CRABP I and II facilitate the mobilisation of retinol from retinyl esters and also the metabolism of retinol to retinoic acid. This proteins could also play a role in the transfer of retinoic acid to the nucleus [17]. In women, the mean CRABP concentration in endometrial carcinomas represents an approximately 4-fold increase over the mean concentration in the normal endometrium and CRBP concentrations tend to be reduced [18].

In the present study, we analysed the content of carotenoids in normal and pathological tissues of corpus uteri, their concentration in tissues and belonging to biochemical groups. We identified predominant carotenoids and determined the percentage of carotenoids belonging to the group of provitamin A. We also attempted to show any differences between the respective groups of tissue samples examined.

\section{Materials and methods}

Subject and sample collection. Material for analysis was obtained from 140 women, aged 32-74, during the planned curettage or operated on for various tumors of the uterine corpus in the Department of Gynaecology, Medical University of Białystok. (see Table 1). Histologically, the material originated from the normal endometrium and myometrium and from tumors of the uterine corpus (epithelial, mesenchymal or mixed tumors).

Cancer tissue carotenoid analyses. The carotenoid pigments were isolated using column chromatography (CC), thin-layer chromatography (TLC) and high-performance liquid chromatography (HPLC). Prior to chromatography, the material was homogenised with acetone under nitrogen in dark glass bottles and the extracts were kept in a refrigerator until analysed. Saponification was carried out with $10 \% \mathrm{KOH}$ in ethanol at $20^{\circ} \mathrm{C}$ for $24 \mathrm{~h}$ in the dark under nitrogen. Column and thin-layer chromatography was used to separate the carotenoids, which were identified by comparison with standard compounds (Hoffman-La Roche and Sigma Company) by a) the behaviour on column chromatography; b) their UV-VIS spectra (Beckman 2400); c) their partition between n-hexane and 95\% ethanol; d) their Rf-values on thin-layer chromatography; e) the presence of allylic OH-group determined by the acid CHCL3 test; f) the epoxide test and g) the mass spectrum [19]. Pigments were determined also by ion - pairing, reverse - phase HPLC. To $1000 \mu \mathrm{l}$ of the

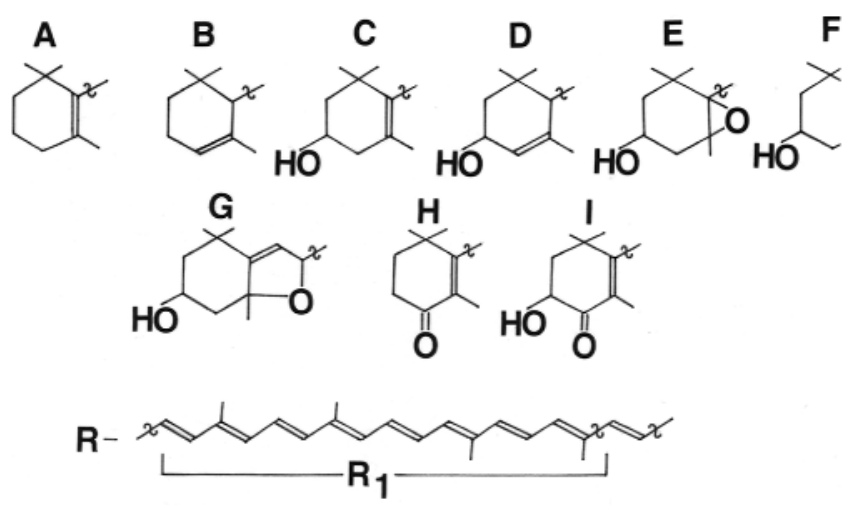

Fig. 1. Structural features of carotenoids from investigated materials (see Table 2).

clear extract, $300 \mu \mathrm{l}$ of ion - pairing reagent was added according to Mantoura and Llewellyn [20]. The HPLC equipment consisted of Shimadzu LC - 6A double - system pump, driven by a gradient programmer Shimadzu SCL-6B and Redone 7125 injector equipped with a $20-\mu 1$ loop. A Shimadzu SPD -6AV UV - VIS spectrophotometer detector set detection on $440 \mathrm{~nm}$ and Shimadzu RF - 535 fluorescence detectors.

Carotenoids as pigment standards were obtained from Hoffman - La Roche Company, Switzerland, International Agency for ${ }^{14} \mathrm{C}$ Determinations, Denmark and Sigma Chemical Company,USA.

Quantitative determinations were performed by UV, VIS spectroscopy [21]. For the structures of carotenoids see Straub [22] and Czeczuga [23].

Statistical analysis. In each group of examined tissues mean values \pm standard deviation (SD) were calculated. The Mann-Whitney test was used to perform statistical analysis.

\section{Results}

The characteristics of study subjects are shown in Table 1. A list of carotenoids obtained form the investigated samples is shown in Table 2 and Fig. 1.

The investigations allowed identification of 13 carotenoids in the tissue samples examined. Six carotenoids: $\beta$-carotene, $\beta$-cryptoxanthin, lutein, neoxanthin, violaxanthin and mutatoxanthin were found in all the samples $(100 \%)$, irrespective of the histological type. $95 \%$ of the tissues contained zeaxanthin. $92.8 \%$ had lutein epoxide, which was absent only from polypus endometrialis. Astaxanthin was identified in all histopathological groups (62.8\%). Hydroxyechinenone was found only in the follicular phase endometrium (2.1\%), as well as in epithelial tumors and other lesions of epithelial origin $(17.9 \%)$, including endometrioid adenocarcinoma (5.7\%). Antheraxanthin (11.4\%) was found in the muscular tissue, in epithelial tumors group and in other epithelial lesions (most commonly in endometrioid adenocarcinoma 5.7\%) and in mixed tumors (mixed epithelial and mesenchymal tumors adenomyoma). Canthaxanthin was identified only in the group of myomas $(2.1 \%)$. Of the 140 tissues examined, only one contained $\beta$-carotene (nonatypical hyperplasia 
Table 1. Characteristic of study subjects (normal tissues/tumors of the uterine corpus).

\begin{tabular}{|c|c|c|c|}
\hline Patients ( $n=140$ ) & Normal tissues & lumors of the uterine corpus & lotal \\
\hline Age $(y \text { cars })^{*}$ & $51.7 \pm 8.43$ & $50.2 \pm 11.1$ & $50.1 \pm 9.7$ \\
\hline Weight $(\mathrm{kg})^{*:}$ & $73.8 \pm 11.89$ & $74.0 \pm 16.51$ & $74.2 \pm 14.72$ \\
\hline PMI* & $25.6 \pm 7.38$ & $29.0 \pm 6.53$ & $28.3 \pm 5.95$ \\
\hline$\Lambda$ ge at menarche (years)* & $14.3 \pm 1.75$ & $14.1 \pm 1.58$ & $14.2 \pm 1.63$ \\
\hline \multicolumn{4}{|l|}{ Menses } \\
\hline Regular & 25 & 62 & 87 \\
\hline Irregular & 0 & 10 & 10 \\
\hline \multicolumn{4}{|l|}{ lamily status (n) } \\
\hline Never married & 1 & 2 & 3 \\
\hline Married & 29 & 108 & 137 \\
\hline Parity $(\mathrm{n})^{*}$ & $1.9 \pm 0.9$ & $2.3 \pm 1.48$ & $2.1 \pm 1.33$ \\
\hline Nulliparous (n) & 2 & 19 & 21 \\
\hline \multicolumn{4}{|l|}{ Menopausal status (n) } \\
\hline Premenopausal & 0 & 0 & 0 \\
\hline Posimenopausal & 5 & 38 & 43 \\
\hline l'amily history of ovary and breast cancer (n) & 0 & 0 & 0 \\
\hline \multicolumn{4}{|l|}{ Ilormonal therapy (n) } \\
\hline$O C$ & 0 & 0 & 0 \\
\hline IIR' & 0 & 0 & 0 \\
\hline
\end{tabular}

$*$ Values are means $\pm \mathrm{SD}$

Table 2. List of carotenoids from investigated materials.

\begin{tabular}{|c|c|c|c|}
\hline Carotenoid & $\begin{array}{l}\text { Summary } \\
\text { formula }\end{array}$ & $\begin{array}{l}\text { Structure } \\
\text { (see Fig. 1) }\end{array}$ & Semisystematic name \\
\hline 1. $\alpha$-carotene & $\mathrm{C}_{40} \mathrm{H}_{56}$ & A-R-B & $\beta \varepsilon$-Carotene \\
\hline 2. $\beta$-carotene & $\mathrm{C}_{40} \mathrm{H}_{56}$ & A-R-A & $\beta, \beta$-Carotene \\
\hline 3. $\beta$-cryptoxanthin & $\mathrm{C}_{40} \mathrm{H}_{56} \mathrm{O}$ & A-R-C & $\beta, \beta$-Caroten-3-ol \\
\hline 4. lutein & $\mathrm{C}_{40} \mathrm{H}_{56} \mathrm{O}_{2}$ & C-R-D & $\beta, \varepsilon$, Carotene- $3,3^{\prime}$-diol \\
\hline 5. zeaxanthin & $\mathrm{C}_{40} \mathrm{H}_{56} \mathrm{O}_{2}$ & C-R-C & $\beta, \beta$-Carotene- $3,3^{\prime}$-diol \\
\hline 6. echinenone & $\mathrm{C}_{40} \mathrm{H}_{54} \mathrm{O}$ & $\Lambda-\mathrm{R}-\mathrm{E}$ & $\beta_{1}, \beta$-Caroten-4-one \\
\hline 7. hydroxyechinenone & $\mathrm{C}_{40} \mathrm{H}_{54} \mathrm{O}_{2}$ & $\Lambda-\mathrm{R}-\mathrm{F}$ & 3-Hydroxy- $\beta, \beta$-caroten-4-one \\
\hline 8. canthaxanthin & $\mathrm{C}_{40} \mathrm{H}_{52} \mathrm{O}_{2}$ & E-R-E & $\beta, \beta$-Carotene- $4,4^{\prime}$-dione \\
\hline 9. astaxanthin & $\mathrm{C}_{40} \mathrm{H}_{52} \mathrm{O}_{4}$ & F-R-F & 3,3'-Dihydroxy- $\beta, \beta$-carotene- $4,4^{\prime}$-dione \\
\hline 10. lutein epoxide & $\mathrm{C}_{40} \mathrm{H}_{56} \mathrm{O}_{3}$ & B-R-G & 5,6-Epoxy-5,6-dihydro- $\beta, \varepsilon$-carotene-3,3'-diol \\
\hline 11. antheraxanthin & $\mathrm{C}_{40} \mathrm{H}_{56} \mathrm{O}_{3}$ & C-R-G & 5,6-Epoxy-5,6-dihydro- $\beta, \beta$-carotene-3,3'-diol \\
\hline 12. neoxanthin & $\mathrm{C}_{40} \mathrm{H}_{56} \mathrm{O}_{4}$ & $\mathrm{G}-\mathrm{R}_{1}-\mathrm{H}$ & $5^{\prime}, 6^{\prime}$-Epoxy-6,7-didehydro- $5,6,5^{\prime}, 6^{\prime}$ tetrahydro- $\beta, \beta$ - carotene- $3,5,3^{\prime}$-triol \\
\hline 13. violaxanthin & $\mathrm{C}_{40} \mathrm{H}_{56} \mathrm{O}_{4}$ & G-R-G & $5,6,5^{\prime}, 6^{\prime}$-Diepoxy- $5,6,5^{\prime}, 6^{\prime}$-tetrahydro- $\beta, \beta$-carotene- $3,3^{\prime}$-diol \\
\hline 14. mutatoxanthin & $\mathrm{C}_{40} \mathrm{H}_{56} \mathrm{O}_{3}$ & $\mathrm{C}-\mathrm{R}_{1}-\mathrm{I}$ & 5,8-Lpoxy-5,8-dihydro- $\beta, \beta$-carotene-3,3'-diol \\
\hline
\end{tabular}


Table 3. Carotenoids composition in the examined tissues of normal endometrium and myometrium.

\begin{tabular}{|c|c|c|c|}
\hline $\begin{array}{l}\text { Carotenoid detected } \\
\quad \text { (see Table 2) }\end{array}$ & $\begin{array}{l}\text { Total content } \\
\qquad(\mu \mathrm{g} / \mathrm{g})^{*}\end{array}$ & $\begin{array}{l}\text { Major carotcnoid } \\
\text { (see Table 2) }\end{array}$ & $\begin{array}{l}\% \text { of carotenoids belonging } \\
\text { to the provitamin } \Lambda \text { group }\end{array}$ \\
\hline \multicolumn{4}{|l|}{ Endometrium } \\
\hline \multicolumn{4}{|l|}{ Endometrium folliculare $(\mathrm{n}=10)$} \\
\hline $2,3,4,5,7,9,10,12,13,14$ & $9.9 \pm 1.56$ & $3,10,13$ & $\begin{array}{c}9.7 \pm 3.86 \\
\wedge \mathrm{p}<0.0001\end{array}$ \\
\hline \multicolumn{4}{|l|}{ Endometrium luteale (n=10) } \\
\hline $2,3,4,5,9,10,12,13,14$ & $\begin{array}{c}4.2 \pm 1.16 \\
\# p<0.0001\end{array}$ & 13,14 & $18.2 \pm 2.57$ \\
\hline Total in endometrium group & $7.1 \pm 3.25$ & & $13.9 \pm 5.43$ \\
\hline \multicolumn{4}{|l|}{ Myometrium (n=10) } \\
\hline $2,3,4,5,9,10,11,12,13,14$ & $\begin{array}{c}4.6 \pm 0.66 \\
{ }^{4} \mathrm{p}<0.0001\end{array}$ & 13,14 & $14.0 \pm 4.13$ \\
\hline $\begin{array}{l}\text { Total in whole group } \\
\text { *Values are means } \pm \text { SD }\end{array}$ & $6.23 \pm 2.91$ & & $13.9 \pm 4.96$ \\
\hline
\end{tabular}

" statistically significant differences relative to the endometrium folliculare group;

${ }^{\wedge}$ statistically significant differences relative to the endometrium luteale group

complex). Echinenone was not detected (see Table 3 and 4).

The total carotenoid content in the samples obtained from endometrium and muscular tissues ranged from 2.6 to $11.8 \mu \mathrm{g} / \mathrm{g}$ tissue, mean $6.3 \pm 2.91 \mu \mathrm{g} / \mathrm{g}$. Mean values in the tissues obtained from the endometrium were higher compared to those from the myometrium but not statistically significant $(7.1 \pm 3.25 / 4.6 \pm 0.66 \mu \mathrm{g} / \mathrm{g})$. In the follicular phase mucosa, the mean carotenoid content was higher than in secretory phase (respectively: $9.9 \pm 1.56$ and $4.2 \pm 1.16 \mu \mathrm{g} / \mathrm{g}$ ).

The highest concentration of provitamin A carotenoids was observed in the tissues of the secretory phase uterine mucosa $(18.22 \pm 2.57 \%)$.

Violaxanthin, $\beta$-cryptoxanthin and lutein epoxide were the predominant carotenoids in the follicular phase, while violaxanthin and mutatoxanthin in the secretory phase mucosa and in the uterine muscle (Table 3).

The total carotenoid content was slightly higher in the material obtained from pathological lesions, ranging between 1.1 and 13.6, mean $6.9 \pm 3.31$ (Table 4). It was the highest in the group of epithelial tumors and lesions of epithelial origin $(8.0 \pm 3.48 \mu \mathrm{g} / \mathrm{g})$, especially in endometrioid adenocarcinoma $(10.8 \pm 1.87 \mu \mathrm{g} / \mathrm{g})$. In mesenchymal tumors, the mean carotenoid content was $5.0 \pm 1.96 \mu \mathrm{g} / \mathrm{g}$, being the highest in leiomyosarcoma $(6.1 \pm 1.13 \mu \mathrm{g} / \mathrm{g})$. The lowest values were noted in the group of mixed tumors $(4.7 \pm 0.56 \mu \mathrm{g} / \mathrm{g})$.

The $\%$ of the provitamin A group carotenoid content was the highest in mesenchymal tumors $(11.7 \%)$. In the remaining two groups the values were similar.

Like in normal tissues, the predominant carotenoids included lutein epoxide (37.1\%), mutatoxanthin
(28.6\%), $\beta$-cryptoxanthin (7.1\%) and violaxanthin $(5.7 \%)$. Lutein epoxide and mutatoxanthin were detected in all the histopathological groups examined, although the latter was not present in endometrioid adenocarcinoma. $\beta$-cryptoxanthin and violaxanthin were found only in the group of epithelial tumors and lesions of epithelial origin (endometrioid adenocarcinoma) (Table 4).

\section{Discussion}

This report describes the total content, major carotenoid and $\%$ of carotenoids belonging to the provitamin A group in normal tissues of the endometrium and myometrium and in tissues of tumors of the uterine corpus. In addition, the results confirm differences between the study groups.

The up-to-now many years' studies have focused mainly on $\beta$-carotene. Our results are the first to allow complete identification of carotenoids of the provitamin A group ( $\alpha$-carotene, $\beta$-carotene, $\beta$-cryptoxanthin, hydroxyechinenone) or epoxide carotenoids (lutein epoxide, mutatoxanthin, violaxanthin).

In 1992 Stahl found differences in the carotenoid content in the respective organs, which varied between individuals. Carotenoids were detected in greatest amounts in the liver, adrenal glands and testicles [24,25]. Despite individual differences in carotenoid patterns, $\beta$-carotene and lycopene were predominant in all the subjects [24]. The function of carotenoids in tissues of the reproductive organs in women and their effects on the reproductive function are unknown. 
Table 4. Carotenoids composition in the examined tissues of tumors of the uterine corpus*. Carotenoids belonging to the provitamin A group: $\beta$-carotene - yielding 2 vitamin A molecules; $\beta$-cryptoxanthin - yielding 1 vitamin A molecule; $\alpha$-carotene - yielding 1 vitamin A molecule; echinenone - yielding 1 vitamin A molecule; hydroxyechinenone - yielding 1 vitamin A molecule.

\begin{tabular}{|c|c|c|c|}
\hline $\begin{array}{l}\text { Carotenoid detected } \\
\quad \text { (see Table 2) }\end{array}$ & $\begin{array}{l}\text { Total content } \\
(\mu \mathrm{g} / \mathrm{g})^{* *}\end{array}$ & $\begin{array}{l}\text { Major carotenoid } \\
\text { (see Table 2) }\end{array}$ & $\begin{array}{l}\% \text { of carotenoids belonging } \\
\text { to the provitamin A group** }\end{array}$ \\
\hline \multicolumn{4}{|l|}{ Epithelial tumors and related lesions } \\
\hline \multicolumn{4}{|l|}{ Endometrioid adenocarcinoma $(\mathrm{n}=20)$} \\
\hline $2,3,4,5,7,9,10,11,12,13,14$ & $10.8 \pm 1.87$ & $3,10,13$ & $12.5 \pm 3.03$ \\
\hline \multicolumn{4}{|l|}{ Endometrial hyperplasia } \\
\hline \multicolumn{4}{|l|}{ Nonatypical hyperplasia } \\
\hline \multicolumn{4}{|l|}{ Simplex $(n=10)$} \\
\hline $2,3,4,5,7,9,10,12,13,14$ & $8.1 \pm 2.92$ & 10,14 & $9.9 \pm 1.44$ \\
\hline \multicolumn{4}{|l|}{$\begin{array}{l}\text { Complex } \\
\text { (adenomatous) }(\mathrm{n}=10)\end{array}$} \\
\hline $1,2,3,4,5,7,9,10,11,12,13,14$ & $\begin{array}{l}7.0 \pm 3.01 \\
" \mathrm{p}<0.01\end{array}$ & $3,10,14$ & $10.2 \pm 2.87$ \\
\hline \multicolumn{4}{|l|}{ Atypical hyperplasia } \\
\hline \multicolumn{4}{|l|}{ Simplex $(n=10)$} \\
\hline $2,3,4,5,7,9,1012,13,14$ & $8.2 \pm 3.18$ & 10,14 & $9.5 \pm 2.51$ \\
\hline \multicolumn{4}{|l|}{ Complex $(\mathrm{n}=10)$} \\
\hline $2,3,4,5,7,9,1012,13,14$ & $7.9 \pm 3.38$ & $3,10,14$ & $11.00 \pm 4.25$ \\
\hline \multicolumn{4}{|l|}{ Endometrial polyp $(\mathrm{n}=10)$} \\
\hline $2,3,4,5,7,9,12,13,14$ & $\begin{array}{l}3.5 \pm 2.18 \\
{ }^{*} \mathrm{p}<0.0001\end{array}$ & 10,14 & $11.7 \pm 2.51$ \\
\hline Total in epithelial tumors and related lesions group & $8.0 \pm 3.48$ & & $10.97 \pm 2.94$ \\
\hline \multicolumn{4}{|l|}{ Mesenchymal tumors } \\
\hline \multicolumn{4}{|l|}{ Smooth muscle tumors } \\
\hline \multicolumn{4}{|l|}{ Leiomyosarcoma $(\mathrm{n}=10)$} \\
\hline $2,3,4,5,9,10,12,13,14$ & $6.1 \pm 1.13$ & 10,14 & $9.9 \pm 2.41$ \\
\hline \multicolumn{4}{|l|}{ Leiomyoma $(n=20)$} \\
\hline $2,3,4,5,8,9,10,12,13,14$ & $4.5 \pm 2.08$ & 10,14 & $12.6 \pm 4.29$ \\
\hline Total in mesenchymal tumors group & $\begin{array}{l}5.05 \pm 1.96 \\
\wedge \mathrm{p}<0.0001\end{array}$ & & $11.7 \pm 3.95$ \\
\hline \multicolumn{4}{|l|}{ Mixed epithelial and mesenchymal tumors } \\
\hline \multicolumn{4}{|l|}{ Adenomyoma $(\mathrm{n}=10)$} \\
\hline $2,3,4,5,9,10,11,12,13,14$ & $\begin{array}{c}4.7 \pm 0.56 \\
\wedge \mathrm{p}<0.0001\end{array}$ & 10,14 & $9.8 \pm 1.33$ \\
\hline Total in whole group & $6.9 \pm 3.31$ & & $11.06 \pm 3.17$ \\
\hline
\end{tabular}

*according to World Health Organization Classification of Tumors, Pathology and Genetics of Tumors of the Breast and Female Genital Organs. Ed. Tavassoli F.A., Devilee P., IARC Press., Lyon, 2003; ** Values are means \pm SD; ${ }^{\#}$ statistically significant differences relative to the endometrioid adenocarcinoma group; ^statistically significant differences relative to the epithelial tumors and related lesions group

Our own research has revealed that in physiological conditions carotenoid concentration is the highest in the follicular phase endometrium. Also the presence of hydroxyechinenone and the predominance of $\beta$-cryptoxanthin are associated with this phase. However, carotenoids of the provitamin A group constitute the 
highest percentage of pigments present in the luteal phase endometrium, which may have a protective effect and prevent pathological changes there. In 2004 Lindquist and Andersson revealed that the normal endometrium expresses $\mathrm{BCO} 1$, the enzyme that catalyses the first step in the conversion of dietary provitamin A carotenoids to vitamin A. Thus it may be responsible for local synthesis of retinol from the carotenoids accumulated in the uterus in cases when their dietary supply is insufficient [26].

In experiments on dogs, Weng et al. observed that uptake of $\beta$-carotene and $\alpha$-carotene by the uterine endometrium and concentration of carotenoids increased after supplementation of higher doses of $\beta$ carotene [4]. In our own experiments using 3 independent methods we detected $\alpha$-carotene in tissues of atypical hyperplasia complex only once. The question is why this carotenoid, present in $50 \%$ of tissues of benign and malignant tumors of the breast and surrounding fatty tissues [27], was observed only sporadically in the present study.

$\beta$-carotene content in human reproductive organs was comparatively lower than that reported for tissues of other human organs [28]. Compared to other neoplastic tissues, tissues of endometrial cancer had the lowest content of $\beta$-carotene [29]. Although group A provitamin carotenoids were not the predominant ones, all the tissues (140 samples) contained $\beta$-carotene and $\beta$-cryptoxanthin. Thus, any tissue obtained from the uterine (normal or pathologic) shows a concentration of vitamin A. The predominant carotenoids were: $\beta$-cryptoxanthin and epoxide carotenoids: lutein epoxide, mutatoxanthin and violaxanthin. Lack of $\beta$-carotene dominance can be due to its involvement in a synergistic action with other carotenoids [30] or with the effect that leads to the reduction in the serum content of other carotenoids [31].

In man, the major source of vitamin A is enzymatic cleavage of $\beta$-carotene and the principal source of retinoic acid is generated in situ in target organs from retinol. Cain et al. were the first to make evidence that in the human endometrium there is an expression of retinol dehydrogenase (hRoDH-4) implicated in the biosynthesis of retinoic acid and this expression is compromised in cancer [10]. So carcinogenesis may be associated with reduced retinoic acid biosynthesis. This process may also involve hydroxyechinenone (provitamin A group), higher values of which were observed in histopathologically diagnosed endometrial carcinoma and which was usually accompanied by antheraxanthin. Worth noting is the fact that both in normal and pathological tissues, the mean total carotenoid content was similar $(6.2 / 6.9 \mu \mathrm{g} / \mathrm{g})$. However, the mean values were the highest in the group with endometrial cancer $(10.8 \mu \mathrm{g} / \mathrm{g})$.
The mean carotenoid content was low in polypus endometrialis, twice as high in hyperplasia, and definitely the highest in endometrial cancer, which may confirm the enzymatic defect in retinol metabolism [10] or metabolic modifications [32] in the neoplastic process. Endometrial transformations under the effect of steroids and retinoids obtained from the culture of the human endometrium by Kamelle et al. suggest that these compounds may have an effect on endometrium transformation, resembling dysplasia or cancer [33].

Similarly, in the group of mesenchymal lesions malignant lesions (leiomyosarcoma) showed higher total carotenoid content, compared to benign lesions (myomas).

Uterine leiomyomas, benign tumors of smooth muscle cells, are the most common pelvic neoplasms in women. In the normal myometrium the values of $\beta$ carotene were more than twofold higher compared to those obtained in leiomyoma group [28,29]. Based on our study outcome, we found no differences in the mean total carotenoid content between both groups, the values were relatively low. However, these groups showed high percentage of carotenoids belonging to group A provitamin (respectively 14.0 and 12.6\%), which may confirm the involvement of retinoic acid in the regulation of myoma growth [13]. Zeaxanthin, present in $95 \%$ of the material examined, was identified in all but 7 samples obtained from the myometrium, while canthaxanthin seemed to be characteristic of myomas.

Authors of numerous studies concluded that the carotenoid effect is due to its prior conversion to vita$\min$ A. However, most dietary carotenoids cannot be converted into retinoids. Some literature data indicate that $\beta$-carotene can bind certain retinoid receptors without being cleaved to form vitamin A [34]. Other mechanisms of carotenoid pigments should also be considered. Asthaxanthin found in $63 \%$ of the tissues examined in the present study has the highest antioxidative properties [35], especially in tissues in which oxygen tension is low (eg. in the uterus). Also $\beta$ carotene may serve to protect the uterine environment from oxidative damage [6]. Chew and Park revealed that dietary carotenoids withouth provitamin A activity, such as lutein, lycopene, asthaxanthin and canthaxanthin demonstrated the immuno-modulatory action (immuno-enhancing action) [36]. Canthaxanthin, $\beta$ carotene $\alpha$-carotene, lutein, $\beta$-cryptoxanthin and lycopene also take part in gap-junction communication [37].

A number of factors can affect carotenoid concentration in tissues. Some aspects of diets (fresh fruit and vegetables) is associated with a decreased risk of endometrial cancer [38], including the amount of fatty tissue that serves as a certain type of carotenoid reservoir [39], or with smoking. It has been shown that the 
atmosphere of high content of free radicals modifies $\beta$ carotene metabolism to obtain forms rich in excentric cleavage metabolites that are structurally similar to retinoids, which could somehow interfere with the metabolism of retinoic acid and thus retinoid signalling [32].

The question whether the presence of carotenoids is the result of accumulation or the effect of a definite function remains open, the more so as carotenoids belonging to different groups may accumulate in blood or tissues, and some of the environmental chemicals may interact with the retinoic acid receptors in the uterus [40]. Thus, the accumulation of carotenoids may be the consequence of this event.

The possible involvement of carotenoids in the biological processes that occur in the uterine endometrium and muscle and the possible efficacy in the prevention of cancer should be explored further.

\section{References}

[ 1] Bo WJ, Smith MS. The effect the retinol and retinoic acid on the morphology of the rat uterus. Anat Rec. 1966;156:5-10.

[2] Chew BP, Archer RG. Comparative role of vitamin A and $\beta$ carotene on reproduction and neonate survival in rats. Theriogenology. 1983;20:459-472.

[ 3] Michal JJ, Heirman LR, Wong TW, Chew BP, Frigg M, Volker L. Modulatory effects of dietary beta-carotene on blood and mammary leukocyte function in periparturient dairy cows. J Dairy Sci. 1994;77:1408-1421.

[4] Weng BC, Chew BP, Wong TS, Park JS, Kim HW, Lepine AJ. $\beta$-carotene uptake and changes in ovarian steroids and uterine proteins during the estrous cycle in the canine. J Anim Sci. 2000;78:1284-1290.

[5] Schweigert FJ, Buchholz I, Schuhmacher A, Gropp J. Effect of dietary $\beta$-carotene on the accumulation of $\beta$-carotene and vitamin A in plasma and tissues of gilts. Reprod Nutr Dev. 2001;41:47-55.

[6] Chew BP, Weng BBC, Kim HW, Wong BS, Park JS, Lepine AJ. Uptake of $\beta$-carotene by ovarian and uterine tissues and effect on steroidogenesis during the estrous cycle in cats. AJVR. 2001;62:1063-1067.

[7] Groothuis PG, McGuire WJ, Vallet JL, Grieger DM, Davis DL. Retinol and estradiol regulation of retinol binding protein and prostaglandin production by porcine uterine epithelial cells in vitro. J Anim Sci. 2002;80:2688-2694.

[ 8] Goodwin TW. The Biochemistry of Carotenoids. Plants. London and New York: Chapman and Hall; 1981.

[ 9] Ross AC, Zolfaghari R, Weisz J. Vitamin A: recent advances in the biotransformation, transport, and metabolism of retinoids. Current Opinion in Gastroenterology. 2001;17:184192.

[10] Cain JM, Zaino R, Shearer D, Bennett A, Olt G, Weisz J. Expression of a retinol dehydrogenase (hRoDH-4), a member of the retinol/steroid dehydrogenase family implicated in retinoic acid biosynthesis, in normal and neoplastic endometria. Am J Obstet Gynecol. 2002;186:675-683.

[11] Wolbach SB, Howe PR. Tissue changes following deprivation of fat soluble A vitamin. $J$ Exp Med. 1925;42:753-777.

[12] Brar AK, Frank GR, Kessler CA, Cedars MI, Handwerger S. Progesterone-dependent decidualization of the human endometrium is mediated by cAMP. Endocrine. 1997;6:301307.
[13] Tsibris JCM, Porter KB, Jazayeri A, Tzimas G, Nau H, Huang H, Kuparadze K, Porter Gw, O'Brien WF, Spellacy WN. Human uterine leiomyomata express higher levels of peroxisome proliferator-activated receptor $\gamma$, Retinoid X Receptor $\alpha$, and all-trans retinoic acid than myometrium. Cancer Res. 1999;59:5737-5744.

[14] Siddiqui NA, Dunlop W, Thomas EP and Redfern CPF. Retinoic acid receptors and binding proteins in endometrial adenocarcinoma. Br J Cancer. 1994;69 (Suppl 21):18.

[15] Deng L, Shipley GL, Loose-Mitchell DS, Stancel GM, Broaddus R, Pickar JH, Davies PJA. Coordinate regulation of the production and signaling of retinoic acid by estrogen in the human endometrium. J Clin Endocrinol Metab. 2003;88: 2157-2163.

[16] Bucco RA, Zheng WL, Wardlaw SA, Davis JT, Sierra-Rivera E, Osteen KG, Melner MH, Kakkad BP, Ong DE. Regulation and localization of cellular retinol-binding protein, retinolbinding protein, cellular retinoic acid binding protein (CRABP), and CRABP II in the uterus of the pseudopregnant rat. Endocrinology. 1996;137:3111-3122.

[17] Siddiqui NA, Loughney A, Thomas EJ, Dunlop W, Redfern $\mathrm{CPF}$. Cellular retinoic binding proteins and nuclear retinoic acid receptors in endometrial epithelial cells. Human Reprod. 1994;9:1410-1416.

[18] Palan PR, Romney SL. Cellular binding proteins for vitamin A in human carcinomas and in normal tissues. Cancer Res. 1980;40:4221-4224.

[19] Vetter W, Englert G, Rigassi N, Schwiester U. Spectroscopic methods. In: Isler O, ed. Carotenoids. Basel and Stuttgart: Birkhauser Verlag; 1971:189-266.

[20] Mantoura RFC, Llewellyn CA. The rapid determination of algal chlorophyll and carotenoid pigments and their breakdown products in natural waters by reverse-phase high-performance liquid chromatography. Anal Chim Acta. 1983;151: 297-314.

[21] Davies BH. Carotenoids. In: Goodwin TW, ed. Chemistry and Biochemistry of Plant Pigments. London-New York: Academic Press; 1976:38-165.

[22] Straub O. Key to Carotenoids. Basel-Boston:Birkhauser Verlag; 1987.

[23] Czeczuga B. Carotenoids. In: Galun M, ed. Handbook of Lichenology. Boca Raton, Florida: CRP Press; 1988:25-34.

[24] Stahl W, Schwarz W, Sundquist AR, Sies H. Cis-trans isomers of lycopene and $\beta$-carotene in human serum and tissues. Arch Biochem Biophys. 1992;294:173-177.

[25] Kaplan LA, Lau JM, Stein EA. Carotenoid composition, concentrations, and relationships in various human organs. Clin Physiol Biochem. 1990;8:1-10.

[26] Lindqvist A and Andersson S. Cell type-specific expression of beta-carotene 15,15'-mono-oxygenase in human tissues. J Histochem Cytochem. 2004;52:491-499.

[27] Czeczuga-Semeniuk E, Wołczyński S, Markiewicz W. Preliminary identification of carotenoids in malignant and benign neoplasms of the breast and surrounding fatty tissue. Neoplasma. 2003;50:280-286.

[28] Palan RP, Mikhail M, Romney SL. Decreased $\beta$-carotene tissue levels in uterine leiomyomas and cancers of reproductive and nonreproductive organs. Am J Obstet Gynecol. 1989;61: 1649-1652.

[29] Palan PR, Goldberg GL, Basu J, Runowicz CD, Romney SL. Lipid-soluble antioxidants: $\beta$-carotene and $\alpha$-tocopherol levels in breast and gynecologic cancers. Gynecol Oncol. 1994; 55:72-77.

[30] Mayne ST. Beta-carotene, carotenoids, and disease prevention in humans. FASEB J. 1996;10:690-701.

[31] Kostic D, White WS, Olson JA. Intestinal absorption, serum clearance, and interactions between lutein and beta-carotene 
when administered to human to human adults in separate or combined oral doses. Am J Clin Nutr. 1995;62:604-610.

[32] Russell RM. The enigma of $\beta$-carotene in carcinogenesis: what can be learned from animal studies. $J$ Nutr. 2004;134: 225-230.

[33] Kamelle S, Sienko A, Benbrook DM. Retinoids and steroids regulate menstrual phase histological features in human endometrial organotypic cultures. Fertil Steril. 2002;78:596602.

[34] Ponnamperuma R, Shimizu Y, Kirchhof S, De Luca L. Betacarotene fails to act as a tumor promoter, induces RAR expression, and prevents carcinoma formation in a two-stage model of skin carcinogenesis in male sencar mice. Nutr Cancer. 2000;37:82-88.

[35] Di Mascio P, Murphy MF, Sies H. Antioxidant defense systems: the role of carotenoids, tocopherols and thiols. Am J Clin Nutr. 1991;53:194-200.

[36] Chew BP, Park JS. Carotenoid action on the immune response. J Nutr. 2004;134:257-261.
[37] Stahl W, Sies H. The role of carotenoids and retinoids in gapjunctional communication. Internat J Vit Nutr Res. 1998;68: 354-359.

[38] Levi F, Fceschi S, Negri E, La Vecchia C. Dietary factors and the risk of endometrial cancer. Cancer. 1993;71:35753581.

[39] Scott KJ, Thurnham DI, Hart DJ, Bingham SA, Day K. The correlation between the intake of lutein, lycopene and $\beta$ carotene from vegetables and fruits, and blood plasma concentrations in a group of women 50-65 years in the UK. $\mathrm{Br} J$ Nutr. 1996;75:409-418.

[40] Paganetto G, Campi F, Varani K, Piffanelli A, Giovannini G, Borea PA. Endocrine-disrupting agents on healthy human tissues. Pharmacol Toxicol. 2000;86:24-29.

Submitted: 22 November, 2007 Accepted after reviews: 11 April, 2008 